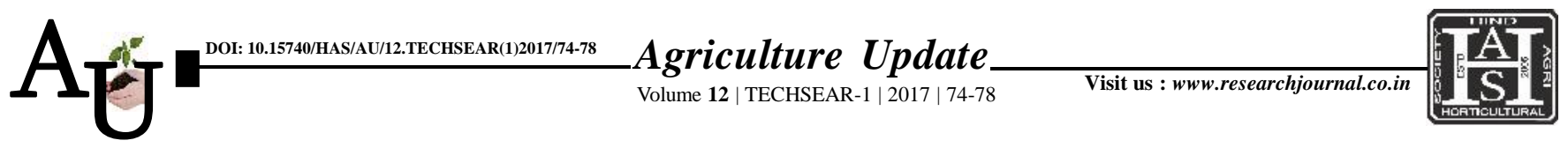

口 e ISSN-0976-6847

\title{
Research автіcle: Neo-nicotinoids and newer insecticides : A biorational approach for managing sucking pests of groundnut
}

\author{
NARESHKUMAR E. JAYEWAR, MILIND M. SONKAMBLE AND SADASHIV \\ S. GOSALWAD
}

Article Chronicle: Received : 05.07.2017;

Accepted : 22.07.2017

KeY Words:

Efficacy, Groundnut, Newer insecticides, Leaf hopper, Thrips

Author for correspondence :

NARESHKUMAR E.

JAYEWAR

Department of Agricultural

Entomology, Vasantrao

Naik Marathwada Krishi

Vidyapeeth, PARBHANI

(M.S.) INDIA

Email:nareshkumarjayewar

@ gmail.com

See end of the article for

authors' affiliations
SUMMARY : Field experiments were conducted during Kharif season of 2010-11, 2011-12 and 2012-13 to evaluate the bioefficacy of newer insecticides (chlorantraniliprole, flubendiamide, spinosad, emamectin benzoate, thiodicarb, fipronil, acetamiprid and thiamethoxam) with conventional insecticides (profenophos, quinalphos, acephate, and chlorpyriphos) against leafhopper and thrips in groundnut. The experiments were conducted in a Randomized Block Design with eight treatments and three replications. The results revealed that the maximum pest control was observed in thiamethoxam $25 \mathrm{WG}$ (200 g/ha) and acetamiprid $20 \mathrm{SP}$ (100 g/ha) and these chemicals also found safe to natural enemies compare to other chemicals, 2010-11, 2011-12 and 2012-13, respectively.

How to cite this article : Jayewar, Nareshkumar E., Sonkamble, Milind M. and Gosalwad, Sadashiv S. (2017). Neo-nicotinoids and newer insecticides : A biorational approach for managing sucking pests of groundnut. Agric. Update, 12(TECHSEAR-1) : 74-78; DOI: 10.15740/HAS/AU/12.TECHSEAR(1)2017/74-78. 